\title{
Multimegawatt Nuclear Reactor Design for Plasma Propulsion Systems
}

\author{
S. N. Jahshan* and T. Kammash ${ }^{\dagger}$ \\ University of Michigan, Ann Arbor, Michigan 48109
}

\begin{abstract}
Material and design innovations are introduced to reduce the mass and volume of an established safe gas-cooled cermet reactor design so that it can be deployed as a multimegawatt electric power source for plasma thrusters including the laser accelerated plasma propulsion system. The design improvements include the deployement of alternate fissile ceramics of uranium, plutonium, or americium and changes in reflectors and vessel specification, without introducing adverse effects on already achieved safety features during launch and operations. The design effort yields several candidates with degrees of mass and volume minimizations reaching $75 \%$ compared to the base design.
\end{abstract}

\section{Introduction}

$\mathbf{I}^{2}$ NTEREST in space exploration has accelerated in recent years and brought with it extensive research actcivity in the area of space propulsion that goes beyond present-day chemical systems. Among those are concepts that rely on the ejection of energetic plasma to produce thrust. Invariably, those systems require multimegawatts of electric power to drive them, and only nuclear systems can provide such power levels and performance. In this paper, we focus on one such system, which utilizes ultrafast lasers to accelerate plasmas to relativistic energies, and address its multimegawatt power requirement. We find that gas-cooled cermet reactors meet the demand, and we provide several designs that appear desireable from the standpoint of size, mass, and safety.

\section{A. Laser Accelerated Plasma Propulsion System}

One of the most promising propulsion systems that could lead to the exploration of the solar system and beyond is the laser accelerated plasma propulsion system (LAPPS). ${ }^{1}$ This system makes use of ultrafast lasers, characterized by femtoseconds pulse length, to accelerate charged particles to relativistic speeds. Experiments at the University of Michigan and the Lawrence Livermore National Laboratory, among others deploying ultrafast lasers, have produced proton beams containing more than $10 E+12$ particles with mean energies of tens of megaelectron volts. In fact, progress is being made so rapidly in laser technology that peak powers will soon be reached that can accelerate protons to their rest mass energies, or to 0.866 the speed of light. The resulting $I_{\mathrm{sp}}$ can be well over $10 E+6 \mathrm{~s}$. This has truly stagering implications for propulsion applications, when coupled with the fact that repetition rates of kilohertz have also been achieved for high-intensity lasers.

The LAPPS concept is based on recent experimental data ${ }^{2}$ in which a kilojoule laser was focused on a tiny spot in a gold foil leading to the ejection of a proton beam with $5.3 \mathrm{-MeV}$ mean energy. It was observed that half of the laser energy was carried by the ejected particles. At a repetition rate of $1 \mathrm{kHz}$, this system is capable of producing $500 \mathrm{~kW}$ of jet power. ${ }^{3}$ Energy balance reveals

Received 25 September 2003; revision received 21 January 2004; accepted for publication 7 February 2004. Copyright (C) 2005 by the American Institute of Aeronautics and Astronautics, Inc. All rights reserved. Copies of this paper may be made for personal or internal use, on condition that the copier pay the $\$ 10.00$ per-copy fee to the Copyright Clearance Center, Inc., 222 Rosewood Drive, Danvers, MA 01923; include the code 0748-4658/05 $\$ 10.00$ in correspondence with the CCC.

*Research Scientist, Department of Nuclear and Radiological Sciences; currently Research Scientist, HSR-12, Mail Stop K 483, Los Alamos National Laboratory, Los Alamos, NM 87545; salim@lanl.gov.

${ }^{\dagger}$ Professor, Department of Nuclear and Radiological Sciences. Associate Fellow AIAA. that $6.1 E+14$ particles were ejected in the beam. For these parameters the specific impulse is about $3.2 \times 10^{6} \mathrm{~s}$, but at a very modest thrust of several millinewtons. At an assumed modest efficiency of $20 \%$, the laser requires a power source of 5 MWe. Clearly a compact high-density power source is called for, and we find that the modified gas-cooled cermet reactor designs developed in this paper meet this challenge.

\section{B. Gas-Cooled Closed-Cycle Cermet Reactor Systems}

Helium-cooled, Brayton cycle refractory materials reactor designs for space power applications have demonstrated calculated cycle efficiencies of about $40 \%$ (Refs. 4 and 5) and higher, depending on the temperature drop available to the system and the heat rejection systems employed. The cermet refractory material application for space power systems has demonstrated calculational and some experimental results that render it extremely attractive based on performance, safety, and reliability. We review these capabilities when new advanced materials and minor design changes are incorporated into the design of this technology where all technical and safety advantages demonstrated earlier are retained. The various suggested material and design modifications can yield, depending on the combination of choices and mission chosen, up to $75 \%$ reduction in mass and volume in the reactor subsystem over previous designs. (The reactor subsystem includes the active core, the reflectors, the control elements and their drives, the vessel, and all its internals.) Whereas to date the limiting parameter in the design and the performance has been the critical active core size, from here on, the proposed design changes and materials will allow for design advances that instead can be directed to optimize all other specifications such as the mechanical, thermal, and structural performance of the overall system. Furthermore, the realizable efficiencies are expected to increase over the previous designs when the rejection temperatures in space are considered to be lower than those assumed for the planetary surface in past applications.

\section{Review of the Cermet Refractory Materials Reactor Designs}

The earliest refractory materials cermet reactor designs were carried out in the mid-1960s. These included the Argonne National Laboratory Nuclear Rocket Program ${ }^{6}$ and the 710 Program work at General Electric Company (GE) for NASA. ${ }^{7-9}$ In the late 1980 s, a modified and improved gas-cooled reactor design based on this technology with several enhancements was proposed for the multimegawatt reactor subsystem in the Strategic Defense Initiative (SDI) proposal by GE. A major part of this nuclear design effort was described in a 1992 publication. ${ }^{10}$ This basic design has been succefully retailored for several space power closed-cycle applications $s^{4,5}$ and for propulsion applications. ${ }^{11}$ 
The high temperature cermet fuel element (Fig. 1) is composed of a refractory metal matrix such as tungsten (W) or molebdenum (Mo) containing granules of a ceramic, for example, uranium oxide, fuel. The ceramic granules are about $10 \mu \mathrm{m}$ diameter on average and comprise up to $60 \%$ of the matrix volume, whereas the refractory metal comprises $40 \%$, just enough to always surround completely and keep separated the fuel granules Coolant channels of 10-20 mm diameters are bored through the cermet matrix. Later (1989 GE SDI proposal or Ref. 10) the coolant channels were made of Mo-rhenium ( $\mathrm{Re}$ ) or W-Re alloy, thus, improving the fissile content retention, the Doppler and resonance absorption reactivity control, and the structural characteristics. There is also a similar alloy (Mo-Re or W-Re) wrapper around the hexagonal fuel element. The fuel element contains several tens of the coolant holes arranged in a hexagonal layout. The fueled region is about $40 \mathrm{~cm}$ long, and there is a $10-12 \mathrm{~cm}$ axial reflector region (containing $\mathrm{Be}$ or $\mathrm{BeO}$ ) aft and fore of the fueled section inside each fuel element as shown in Fig. 2. The overall length of the fuel element is typically $60-65 \mathrm{~cm}$. The fuel element in Fig. 2 has 61 coolant channels, of $1.3 \mathrm{~mm}$ diameter each, and a flat-to-flat thickness of $23.16 \mathrm{~mm}$.

Figure 3 is a planar layout of a typical ${ }^{10}$ reactor subsytem made of a lattice of these fuel elements, which are arranged in a cylindrical configuration and are held in place by an upper plate (Fig. 4). In this

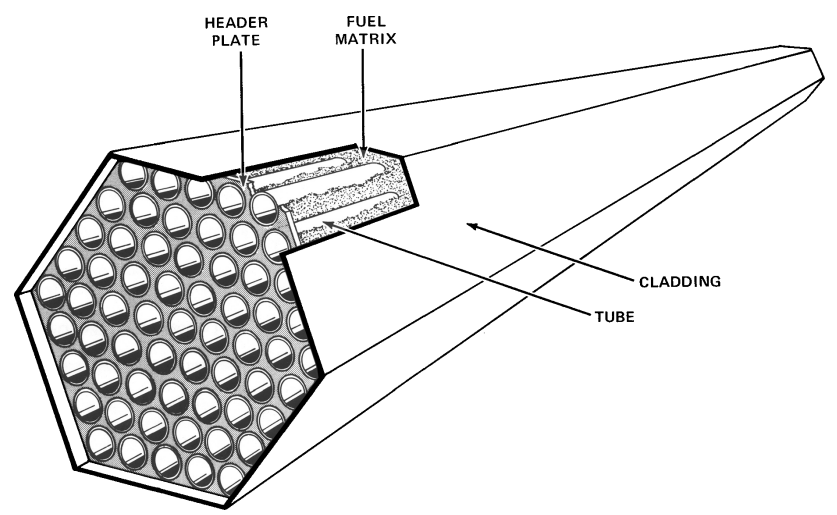

Fig. 1 Typical cermet fuel segment: wrapper, coolant flow tubes, and cermet matrix made of refractory metal and fissile bearing ceramic. particular design, there are two fuel enrichments for the purpose of flattening the radial power ditribution. In the current work, we look at just the highest allowed fissile loading because the reactors we consider, while are similar in layout, have many fewer fuel elements; thus, they are considerably smaller and do not require as much power shaping. There are three safety (shutdown) rods arranged within this latice. The active control material is highly enriched (in $B^{10}$ ) sintered $\mathrm{B}_{4} \mathrm{C}$, with a $\mathrm{Be}$ or $\mathrm{BeO}$ rod follower. Each fuel element has a $10-12 \mathrm{~cm}$ long section made of $\mathrm{BeO}$ filler at about $80 \%$ solid volume fraction (to allow for coolant flow) for the fore and aft axial reflector regions. The radial reflector region is usally made of a $10-12 \mathrm{~cm}$ thick $\mathrm{Be}$ or $\mathrm{BeO}$ cylindrical shell around the active core, with coolant flow channels to keep the reflector cooled. The radial reflector is made of fixed sections and rotating sections, where the rotating sections are control drums of the same material,

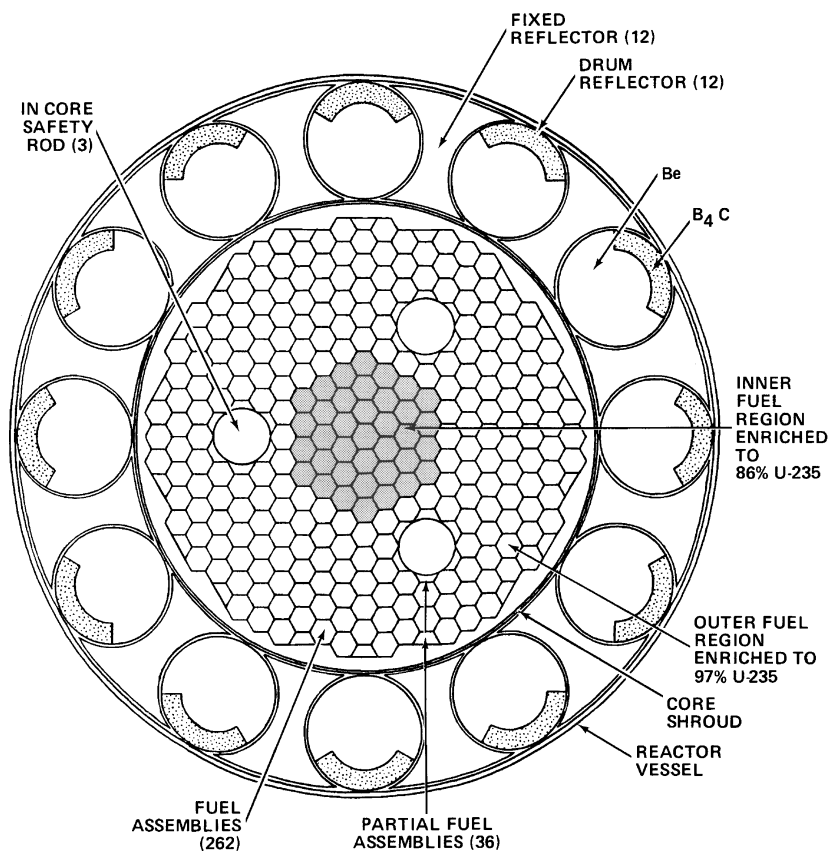

Fig. 3 Midcore cross-sectional view of reactor subsystem, location of safety rods, control drums, and fixed radial reflector segments.
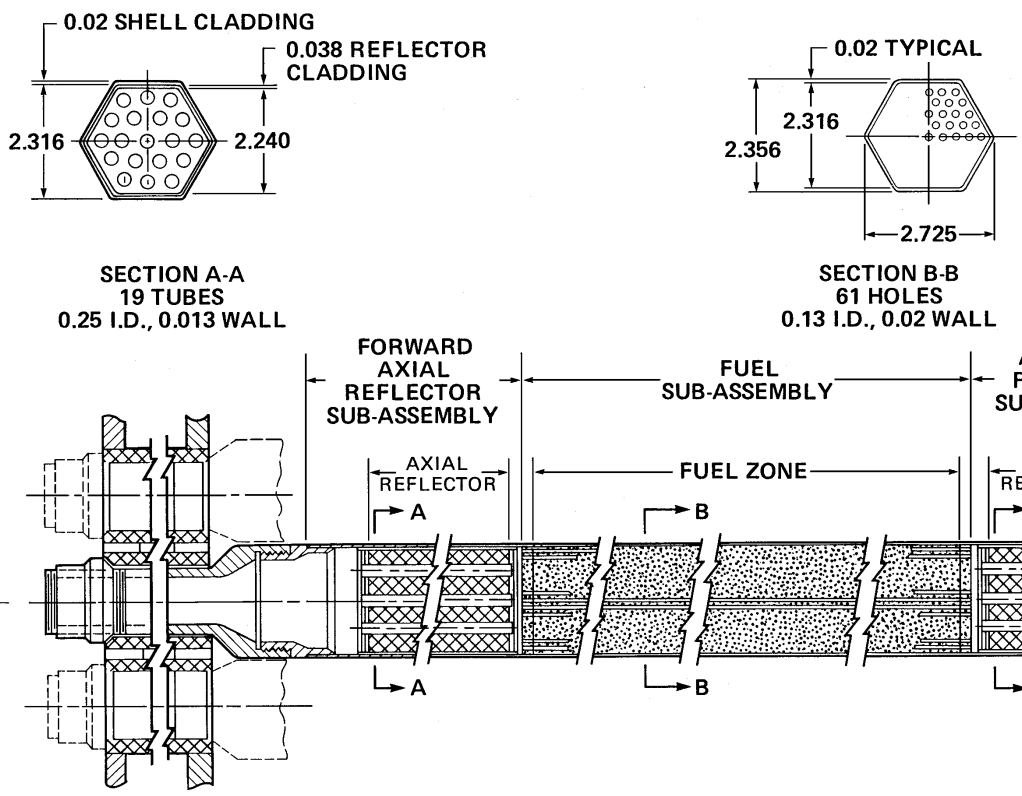

Fig. 2 Fuel element, detail of fueled region, axial reflector regions, coolant ducts, and fore segment as it attaches to core plate (dimensions in millimeters). 
Table 1 Active core materials combinations, achievable temperatures, and safety conditions for uranium ceramic fueled cermet systems

\begin{tabular}{|c|c|c|c|}
\hline Matrix/clad & $\begin{array}{l}\text { Fuel candidates, } \\
\text { compatable to matrix }\end{array}$ & Performance characteristics & Basic features \\
\hline W/W-Re & $\mathrm{UO}_{2}$ & High temperature compatabilty to $2500 \mathrm{~K}$ with $\mathrm{UO}_{2}$ & $\begin{array}{l}\text { Subcritical when immersed in water. } \\
\text { Three in-core rods required. } \\
\text { BeO radial reflectors recommended. }\end{array}$ \\
\hline Mo/Mo-Re & $\mathrm{UO}_{2}$ & High temperature compatabilty to $2250 \mathrm{~K}$ with $\mathrm{UO}_{2}$ & $\begin{array}{l}\text { Subcritical when immersed in water. } \\
\text { Three in-core rods required. } \\
\text { Be radial reflecors recommended. }\end{array}$ \\
\hline Mo/Mo-Re & UN & High temperature compatabilty to $1900 \mathrm{~K}$ with UN & $\begin{array}{l}\text { Subcritical when immersed in water. } \\
\text { Three in-core rods required. } \\
\text { Be radial reflectors recommended. }\end{array}$ \\
\hline
\end{tabular}

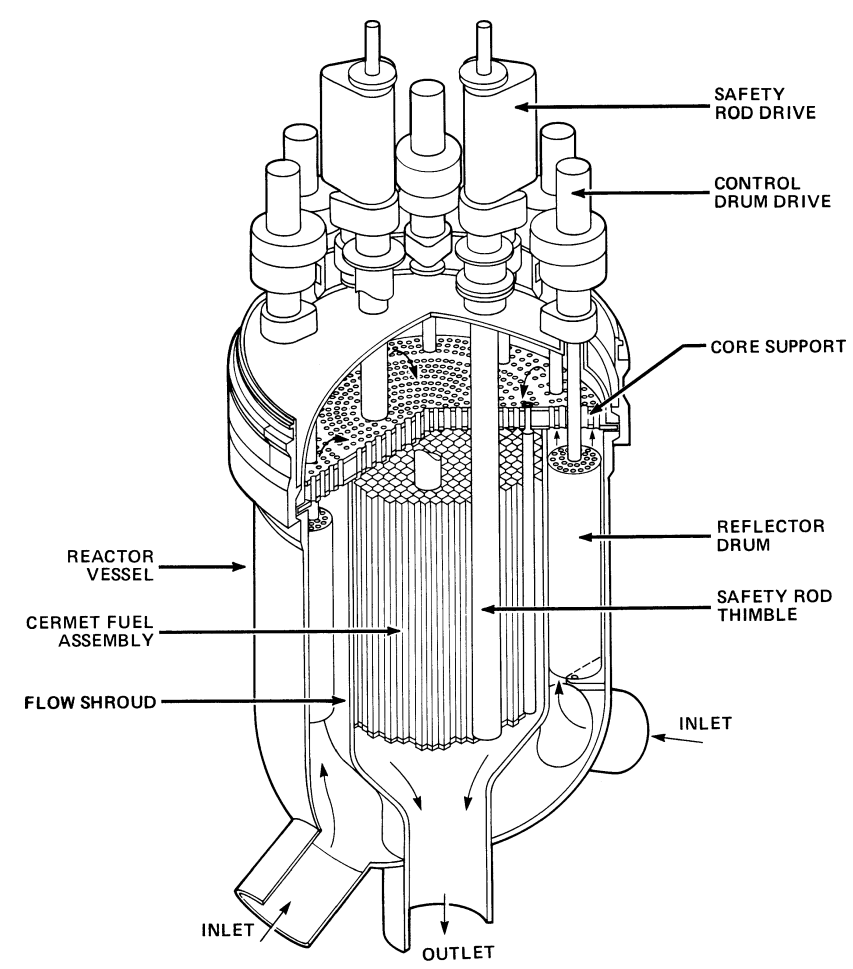

Fig. 4 Reactor subsystem, radial reflector region and drums, core support plate, coolant flow scheme, and control rod and drum drives.

but containing a poison $\left(\mathrm{B}_{4} \mathrm{C}\right)$ region that is rotated away from, or toward, the core as needed for operations control. Figure 4 is a three-dimensional view of the typical closed-cycle design achieved in the late 1980 s. $^{10}$

The typical achievable temperatures, and reactor core materials are given in Table 1 for the current state-of-the-art design. Our proposed material substitutions and design changes are not expected to affect the peak temperatures achievable, power densities, or heat conduction and transfer characteristics, but will introduce major reductions in mass and volume of the reactor subsytem.

\section{Material and Design Changes}

\section{A. Review of Basic Properties of Component Materials}

In the past three to four decades, during which several research activities (of a few years each) considered and developed refractory cermet reactor designs, the various materials used in the design of cermet reactors were narrowed down to a select small group. First there is the choice of base refractory metals, which have been narrowed down to Mo or W, with wrappers and coolant ducts made, respectively, from Mo or $\mathrm{W}$ alloyed with a small (under $5 \mathrm{wt} \%$ ) Re content. Table 2 lists the densities and temperatures involved for these refractory metals. All three metals have very high densi-
Table 2 Base metal options for refractory cermet reactor fuel elements

\begin{tabular}{lcc}
\hline Base metal & $\begin{array}{c}\text { Melting } \\
\text { temperature, K }\end{array}$ & $\begin{array}{c}\text { Density, g/cm } \\
\text { metal }\end{array}$ \\
\hline $\mathrm{W}$ & 3680 & 19.3 \\
$\mathrm{Mo}$ & 2890 & 10.2 \\
$\mathrm{Re}$ (for alloying & 3463 & 21.0 \\
$\quad$ with W or Mo) & & \\
\hline \hline
\end{tabular}

Table 3 Densities and melting point temperatures for the ceramic fuel options

\begin{tabular}{lccc}
\hline \hline Fuel & $\begin{array}{c}\text { Theoretical } \\
\text { density, } \mathrm{g} / \mathrm{cm}^{3}\end{array}$ & $\begin{array}{c}\text { Melting } \\
\text { temperatue, } \mathrm{K}\end{array}$ & $\begin{array}{c}\text { Peak He gas exit } \\
\text { temperature chosen, K }\end{array}$ \\
\hline $\mathrm{UO}_{2}$ & 10.97 & 3100 & 1700 (conservative) \\
$\mathrm{UN}^{2}$ & 14.3 & 3078 & 1400 (conservative) \\
$\mathrm{PuO}_{2}$ & 11.5 & 2673 & 1700 (conservative estimates) \\
$\mathrm{PuN}_{\mathrm{AmO}}$ & 14.4 & 2823 & 1400 (conservative estimates) \\
$\mathrm{AmN} ?$ & $>11.5$ & $>2250 ?$ & $?$ \\
\hline \hline
\end{tabular}

ties, good compatibility with the ceramic fuel granules, excellent strengths and heat conductivities, and easy manufacturability. The cermets are made with one of the two metals, Mo or W, and Re is the alloying agent used for the coolant ducts and the fuel element wrappers. The advantage of $\mathrm{W}$ over Mo in higher temperature achievable is counterbalanced by its disadvantage in density. The alloying agent metal, $\mathrm{Re}$, is very expensive but has several key and very desirable properties, such as increasing the ductility of the Mo or W and other nuclear criticality control characteristics. The Re has several important kiloelectron volt resonances that provide important Doppler broadening effects that are the main temperature reactivity control contributers to the design. In fact, the relative contributions of the three metals to the Doppler effect is highest for Re, followed by those for W, then Mo. The Re epithermal absorption is also a very strong contributor to the safety requirements when the fast neutron spectrum (normal operation) turns to thermal in the flooded and the buried accident scenarios. Such favorable properties of Re have been utilized in other novel ways, such as for power shaping and fuel bowing prevention. ${ }^{4,5,10,11}$ In fact, without these unique nuclear and metallurgical properties of $\mathrm{Re}$, the refractory cermet reactor would not be a convincing proposition.

The candidate fuels for the refractory cermet fuel element are shown in Table 3. A fast neutron fission reaction with $\mathrm{U}^{235}$ yields about 2.4 neutrons, with $\mathrm{Pu}^{239}$ almost 3 neutrons, and with $\mathrm{Am}^{242 \mathrm{~m}}$ almost 7 neutrons. The corresonding plutonium or americium oxides (or nitrides) densities are also favorable compared to uranium ceramics. The uranium oxide is the best known fuel and allows a peak gas coolant temperature of $2250 \mathrm{~K}$. The plutonium oxides or americium oxides are expected to sustain similar temperatures. The 
nitrides are attractive due to the higher densities of heavy metal loaded in the cermet, but there is considerably less experience with the nitride fuels, as well as known limitations, such as the dissociation of nitrogen from the heavy metals at temperatures well below the corresponding melting points unless retained under nitrogen pressure. $^{12}$

The reflector materials are beryllium $(\mathrm{Be})$ and beryllium oxideas $(\mathrm{BeO})$ listed in Table 4 . The mass advantage due to the lower density of $\mathrm{Be}$ is counterbalanced by the peak temperature allowed for $\mathrm{BeO}$ over Be. In the many reactor designs we have considered, $, 4,5,10,11$ we have found that both reflector materials are equivalent in their effect on the system eigenvalue. Thus, we are left with the simple choice between higher temperature $(\mathrm{BeO})$ and lower density $(\mathrm{Be})$. Other less important material properties, such as manufacturability, are not considered in the comparison.

The base fuel element design we consider is like the one in Fig. 2, with various active fuel lengths and aft or fore reflector extents. This is a hexagonal fuel element of $23.16 \mathrm{~mm}, 0.2-\mathrm{mm}$ coolant duct wall and wrapper thickness, and 61 coolant ducts per fuel element (in the active fuel section) having an inner diameter of $1.3 \mathrm{~mm}$ each. The possible variations in coolant duct modifications are given in Table 5. Furthermore, the coolant duct wall thickness or the wrapper thickness of $0.2 \mathrm{~mm}$ may be changed to 0.3 or other values as the design consideration may require. In this work, we continue to use the Ref. 10 design specifications for the coolant ducts $(1.3 \mathrm{~mm}$ inner diameter and $0.2-\mathrm{mm}$ wall thickness) so that the materials and thermal comparisons remain easy to make at this preliminary stage.

There are at least three excellent candidates for reactor vessel materials: TZM, Incoloy, and stainless steel. TZM has the highest density (disadvantage) but the highest temperature tolerance, ductility, and tensile strength. The content of metals that have thermal and epithermal resonace absorption in the vessel material alloy also contribute to the safety requirements of the design.

\section{B. Reference Cermet Reactor Model}

Figure 3 is a $\mathrm{Mo}-\mathrm{UO}_{2}$ based cermet reactor with $\mathrm{Mo}-\mathrm{Re}$ coolant ducts and wrappers around the fuel elements. ${ }^{10}$ There are 3 central safety rods that occupy the cross-sectional area of 4 fuel elements

Table 4 Reflector materials and relevant properties

\begin{tabular}{lccc}
\hline \hline $\begin{array}{l}\text { Reflctor } \\
\text { material }\end{array}$ & $\begin{array}{c}\text { Melting } \\
\text { temperature, } \mathrm{K}\end{array}$ & $\begin{array}{c}\text { Density, } \\
\mathrm{g} / \mathrm{cm}^{3}\end{array}$ & Application \\
\hline $\mathrm{Be}$ & 1560 & 1.85 & $\begin{array}{c}\text { Use for radial reflector with lower } \\
\text { coolant exit temperatures } \\
\text { Always to be used for axial reflector }\end{array}$ \\
\hline
\end{tabular}

Table 5 Coolant flow design changes possible

\begin{tabular}{lc}
\hline $\begin{array}{l}\text { Number of coolant ducts } \\
\text { per fuel element }\end{array}$ & $\begin{array}{c}\text { Coolant duct } \\
\text { diameter, mm }\end{array}$ \\
\hline 61 & $1.3,1.4,1.5,1.6,1.7$ \\
91 & $1.3,1.4,1.5$ \\
127 & $1.3,1.4$ \\
\hline \hline
\end{tabular}

each and 12 rotary control drums. The neutron poison in both of these control/safety element types is sintered $\mathrm{B}_{4} \mathrm{C}$ enriched to $90 \mathrm{wt} \% \mathrm{~B}_{10}$. The overall active core diameter is about $40 \mathrm{~cm}$, and the active core height is about $39 \mathrm{~cm}$. There is an $11-\mathrm{cm} \mathrm{BeO}$ axial reflector region fore and aft of the active core and a $12-\mathrm{cm}$-thick Be radial reflector. The reference [beginning of life, cold (296 K) reactor multiplication factor with all rods and drums withdrawn] is 1.06. (It is common to refer to the multiplication factor as the eigenvalue, which refers to the neutron transport equation solution describing the problem.) Further details of this design and its safety and performance capabilities are in Ref. 10. In the various reactor designs we consider later, the same arrangement is retained, except for the total number of fuel elements. In some of the smallest reactor designs, only two instead of three central safety rods are employed.

\section{Safety and Reactivity Design Features/Considerations of the Reference Reactor}

This reference reactor meets a number of strict safety operation conditions and safety conditions for launch and reentry of the assembled (shutdown) reactor. The various eigenvalues of the beginning of reactor life (BOL) configurations for two designs ${ }^{5,10}$ are shown in Table 6. There is also an allowance of a reactivity defect due to over $2 \%$ burnup of the $\mathrm{U}^{235}$ fuel in relevant cases.

\section{Preliminary Pu and Am Considerations}

1. Weapon Grade Plutonium Ceramics Substitutions: $\mathrm{PuO}_{2}$ in place of $\mathrm{UO}_{2}$

A simple Monte Carlo N-particle transport code system (MCNP) nuclear transport model of the reference reactor was built. This has an active core of height $H$ equal to diameter $D=40 \mathrm{~cm}$ and a radial reflector of $\mathrm{Be}$ at 0.80 density (to allow for coolant flow) and an aft and fore $\mathrm{BeO}$ (also at 0.80 theoretical density) axial reflector of $12 \mathrm{~cm}$ each. The resulting eigenvalue of this model is above 1.06 with considerable conservatism applied. From previous analyses, ${ }^{4,5,10,11}$ we know that the reactivity swing for the various accident and safety scenarios is about $12 \%$ in eigenvalue, down to an eigenvalue of about 0.93 , and is achieved by the control rod and reflector drums movements. Several of these scenarios were reevaluated for our model and continued to fall in the same range. Using this preliminary model, we performed a few evaluations of fuel substitution effects.

The theoretical density of $\mathrm{PuO}_{2}$ is $11.46 \mathrm{~g} / \mathrm{cm}^{3}$ as compared to $10.0 \mathrm{~g} / \mathrm{cm}^{3}$ for $\mathrm{UO}_{2}$. Considering the variations in these densities due to isotopic enrichments, we proceeded to perform a preliminary Monte Carlo neutron transport analysis by making $\mathrm{Pu}^{239}$ for $\mathrm{U}^{235}$ atomic substitutions and searching for a new $H=D$ that yields an eigenvalue of 1.06. This simple design substitution achieves this base eigenvalue at an active core height and diameter of $H=D=27 \mathrm{~cm}$. This is a reduction of about $70 \%$ in the mass and volume of the active core because the reduction is proportional to the ratios of $H$ and $D$ squared, or $(27 / 40)^{3} \sim 0.31$. A corresponding reduction is also achieved in the mass and volume of the enveloping reflectors and vessel and other components such as the rod drives' masses and volumes, although these are not as readily evaluated.

The resultant decrease in core size can be taken advantage of in at least two ways. The active core height and diameter can be simply decreased, with the automatic reduction in the overall system size

Table 6 Expected base safety configurations eigenvalues

\begin{tabular}{|c|c|c|c|c|c|c|c|}
\hline CERMET & Application & $\begin{array}{l}\text { All rods } \\
\text { out, all } \\
\text { drums open }\end{array}$ & $\begin{array}{l}\text { All rods } \\
\text { in, all } \\
\text { drums open }\end{array}$ & $\begin{array}{c}\text { All rods } \\
\text { out, all } \\
\text { drums closed }\end{array}$ & $\begin{array}{c}\text { All rods } \\
\text { in, all } \\
\text { drums closed }\end{array}$ & $\begin{array}{l}\text { All rods in; all drums } \\
\text { closed; compacted and } \\
\text { buried in earth }\end{array}$ & $\begin{array}{l}\text { All rods in, all drums } \\
\text { closed, flooded } \\
\text { in ocean }\end{array}$ \\
\hline $\mathrm{Mo}-\mathrm{Re} / \mathrm{UO}_{2}$ & $\begin{array}{l}\text { Strategic defence } \\
\text { initiative/ } \\
\text { multimegawatt-II }^{10}\end{array}$ & 1.06 & 0.96 & 0.98 & 0.91 & 0.95 & 0.97 \\
\hline Mo-Re/UN & $\begin{array}{l}\text { Planetary } \\
\text { base power }^{5}\end{array}$ & 1.05 & 0.97 & 0.99 & 0.92 & 0.96 & 0.98 \\
\hline
\end{tabular}


and mass. However, one can more wisely use these advantages to optimize the overall design and move away from the constraint that has been so far the primary determinant of the design: the minimum achievable active core mass.

2. Americium Ceramic Substitutions: ${ }^{242 \mathrm{~m}} \mathrm{Am} \mathrm{O}_{2}$ in Place of $\mathrm{UO}_{2}$

We briefly review the americium nuclear properties and obtainability. There are three long-lived isotopes of americium (Ref. 13), $\mathrm{Am}^{241}$ with $T_{1 / 2}=433$ year, $\mathrm{Am}^{242 \mathrm{~m}}$ with $T_{1 / 2}=140$ or 152 year and $\mathrm{Am}^{243}$ with $T_{1 / 2}=7400$ year. $\mathrm{Am}^{241}$ is the product of $\mathrm{Pu}^{241}$ natural decay, and $\mathrm{Am}^{242 \mathrm{~m}}$ is produced from activation of $\mathrm{Am}^{241}$ in a reactor. The two can be separated by electromagnetic means. Am ${ }^{242 m}$ has been proposed for fissile applications ${ }^{14}$ and for fusion-fission applications, ${ }^{15}$ among others. The fissile characteristics (number of neutrons reemitted from fission and fission cross sections) are optimal when deployed in a very fast reactor sytem as in the refractory cermets we are considering.

The deployment of americum oxide $\left({ }^{242 \mathrm{~m}} \mathrm{Am} \mathrm{O}_{2}\right.$, theroretical density $11.68 \mathrm{~g} / \mathrm{cm}^{3}$ ) leads to similar increases in the eigenvalue due to the higher fission cross section and the fission neutron yields. This isotopic substitution has a greater effect than the $\mathrm{Pu}^{239}$ substitution, and a systematic reduction in $H$ and $D$ of the active core till the reference eigenvalue is $\sim 1.06$, which yields $H=D=20.5 \mathrm{~cm}$, or a reduction of $(20 / 40)^{3} \sim 0.125$ of the original core volume and mass.

These major decreases in core mass and volume justify a redesign of the typical cermet reactor system with handsome advantages in mass and volume savings and in performance enhancements. Table 7 demonstrates that reactor subsystem components remain compatible and retain the refractory temperature limits and base design safety conditions.

For closed-cycle systems, and based on the results in Table 7, we have decided to choose the Mo-based rather than W-based cermets due to the major advantage in weight and the minor disadvantage in the attainable peak temperature. Both the $\mathrm{Be}$ as well as the $\mathrm{BeO}$ can be used now for the radial reflector, but we decided to use $\mathrm{BeO}$ in all reflector locations for added safety and transient analysis margin.

In Table 8, we present three base reactor models employing the three dioxides of the heavy metals under consideration in Mo-Re cermet systems. Note that we have allowed the height to be larger than the diameter in these designs in anticipation of the need for adequate core height for heat transfer to the coolant gas. The overall mass estimate (kilograms).

Representative dimensions and masses of potential metal-dioxide cermet reactor subsystems.

We do not consider the $\mathrm{Am}^{242 \mathrm{~m}}$-based cermets beyond this point because it is understood that there may be several technical or administrative issues with this controlled material; however, we present a brief mass and dimensions evaluations of the substitutions of the oxide by a nitride and the increase of the reflector thickness to $18 \mathrm{~cm}$ in both the $\mathrm{Pu}$ and $\mathrm{U}$ systems.

\section{E. Reflector Redesign}

The radial and axial reflectors were allocated a thickness between 10 and $12 \mathrm{~cm}$ only in the past design. This was motivated ${ }^{10}$ in part by a desire to ensure the safety scenarios at launch conditions. Specifically, it was and is still desired to retain the reactor in a subcritical configuration due to possibility of submersion in water, or due to burial in soil without the loss of the reflector in some of the postulated accident scenarios. This can indeed still be met with some increases in the reflector thickness, especially when thermal (or epithermal) neutron absorbers such as Re are incorporated in the vessel, vessel shroud, or lining, or the reflector regions. As we show in the selected cases, an increase of the reflector thickness to as much as $18 \mathrm{~cm}$ yields considerable advantage in further mass and

Table 7 Active core materials combinations, achieveable temperatures, and safety conditions for cermet systems with the plutonium and americium ceramics

\begin{tabular}{|c|c|c|c|c|}
\hline Matrix/clad & $\begin{array}{l}\text { Fuel candidates } \\
\text { compatible to matrix }\end{array}$ & $\begin{array}{l}\text { Performance } \\
\text { characteristics }\end{array}$ & $\begin{array}{l}\text { Peak coolant } \\
\text { temperature, } \mathrm{K}\end{array}$ & Basic features \\
\hline W/W-Re & $\mathrm{UO}_{2}$ or $\mathrm{PuO}_{2}$ or $\mathrm{Am}^{242 \mathrm{~m}} \mathrm{O}_{2}$ & High temperature compatibilty to $2500 \mathrm{~K}$ & 2250 & $\begin{array}{l}\text { Subcritical when immersed in water, or buried. } \\
\text { BeO radial reflectors recommended }\end{array}$ \\
\hline Mo/Mo-Re & $\mathrm{UO}_{2}$ or $\mathrm{PuO}_{2}$ or $\mathrm{Am}^{242 \mathrm{~m}} \mathrm{O}_{2}$ & High temperature compatibilty to $2250 \mathrm{~K}$ & 2000 & $\begin{array}{l}\text { Subcritical when immersed in water, or buried. } \\
\text { Be or BeO radial reflecors. }\end{array}$ \\
\hline Mo/Mo-Re & PuN or UN & High temperature compatibilty to $1900 \mathrm{~K}$ & 1700 & $\begin{array}{l}\text { Subcritical when immersed in water, or buried. } \\
\text { Be or BeO radial reflectors. }\end{array}$ \\
\hline
\end{tabular}

Table 8 Representative dimensions and masses of potential metal-dioxide cermet reactor subsystems

\begin{tabular}{lcccc}
\hline \hline Active core materials & $\begin{array}{c}\text { Fuel ceramic (85-92) } \\
\text { \%theoretical density (td) }\end{array}$ & $\begin{array}{c}\text { Active core } \\
\text { and } D, \mathrm{~cm}\end{array}$ & $\begin{array}{c}\text { Reflector (Be or } \\
\mathrm{BeO}) \text { at } 80 \% \text { td, cm }\end{array}$ & $\begin{array}{c}\text { Overall mass } \\
\text { estimate, kg }\end{array}$ \\
\hline $\mathrm{Mo}-\mathrm{Re} / \mathrm{Mo}-\mathrm{UO}_{2}$ & $\mathrm{UO}_{2}(97 \% \mathrm{U}-235)$ & $H=D$ 39-40 & $A R^{*}=R R^{\dagger} 10-12$ & $H=75 D=60-65$ \\
$\mathrm{Mo}-\mathrm{Re} / \mathrm{Mo}-\mathrm{PuO}_{2}$ & $\mathrm{PuO}_{2}(95 \% \mathrm{Pu}-239)$ & $H=D 29-30$ & $A R=R R 10-12$ & $H=65 D=50-55$ \\
$\mathrm{Mo-Re} / \mathrm{Mo} \mathrm{Am}^{242 \mathrm{~m}} \mathrm{O}_{2}$ & $\mathrm{Am}^{242 \mathrm{~m} \mathrm{O}_{2}}$ & $H=D 18-20$ & $A R=R R 10-12$ & $H=40-45 D=45-50$ \\
\hline \hline
\end{tabular}

${ }^{*} A R$-axial reflector. ${ }^{\dagger} R R$-radial reflector.

Table 9 Representative dimensions and masses of potential uranium cermet reactor subsystems (nitride substitution, and reflector modifications)

\begin{tabular}{|c|c|c|c|c|c|}
\hline Active core materials & $\begin{array}{l}\text { Fuel ceramic } \\
\text { at }(85-92) \% \text { td }\end{array}$ & $\begin{array}{l}\text { Active core } \\
H \text { and } D, \mathrm{~cm}\end{array}$ & $\begin{array}{c}\text { Reflector BeO } \\
\text { shell at } 80 \% \text { td, cm }\end{array}$ & Vessel $H$ and $D, \mathrm{~cm}$ & $\begin{array}{l}\text { Mass (estimate), } \\
\text { reactor, vessel, kg }\end{array}$ \\
\hline $\mathrm{Mo}-\mathrm{Re} / \mathrm{Mo}-\mathrm{UO}_{2}$ & $\mathrm{UO}_{2}(97 \%$ enriched $)$ & $\mathrm{H}=\mathrm{D} 40$ & $A R^{*}=R R^{\dagger} 10-12$ & $H=70-75 D=62-68$ & 1020,610 \\
\hline $\mathrm{Mo}-\mathrm{Re} / \mathrm{Mo}-\mathrm{UO}_{2}$ & $\mathrm{UO}_{2}(97 \%$ enriched $)$ & $H=D 31$ & $A R=14 R R=18$ & $H=60-65 D=70-71$ & 650,560 \\
\hline Mo-Re/Mo-UN & UN (97\% enriched) & $H=D 37$ & $A R=12 R R=12$ & $H=64-66 D=62-63$ & 820,470 \\
\hline Mo-Re/Mo-UN & UN (97\% enriched) & $H=D 25$ & $A R=14.0 R R=19.0$ & $H=53-58 D=64-65$ & 320,520 \\
\hline
\end{tabular}

${ }^{*} A R$-axial reflector. ${ }^{\dagger} R R$-radial reflector. 
Table 10 Representative dimensions and masses of potential plutonium cermet reactor subsystems (nitride substitution and reflector modifications)

\begin{tabular}{lccccc}
\hline \hline Active core materials & $\begin{array}{c}\text { Fuel ceramic } \\
\text { at (85-92) \%td }\end{array}$ & $\begin{array}{c}\text { Active core } \\
H \text { and } D, \mathrm{~cm}\end{array}$ & $\begin{array}{c}\text { Reflector }(\mathrm{Be} \text { or BeO) } \\
\text { shell at 80\%td, cm }\end{array}$ & Vessel $H$ and $D, \mathrm{~cm}$ & $\begin{array}{c}\text { Overall mass } \\
\text { (estimate), kg }\end{array}$ \\
\hline $\mathrm{Mo-Re} / \mathrm{Mo}-\mathrm{PuO}_{2}$ & $\mathrm{PuO}_{2}(95 \% \mathrm{Pu}-239)$ & $H=D=28$ & $A R^{*}=R R^{\dagger} 12$ & $H=55-57 D=53-54$ & 370,380 \\
$\mathrm{Mo}-\mathrm{Re} / \mathrm{Mo}-\mathrm{PuO}_{2}$ & $\mathrm{PuO}_{2}(95 \% \mathrm{Pu}-239)$ & $H=24 D=18$ & $A R=14 R R=18$ & $H=56-58 D=55-57$ & 310,370 \\
$\mathrm{Mo}-\mathrm{Re} / \mathrm{Mo}-\mathrm{PuN}$ & $\mathrm{PuN}^{(95 \% \mathrm{Pu}-239)}$ & $H=D 19-20$ & $A R=10-12 R R=10-12$ & $H=42-46, D=42-45$ & 290,310 \\
$\mathrm{Mo}-\mathrm{Re} / \mathrm{Mo}-\mathrm{PuN}$ & $\mathrm{PuN}(95 \% \mathrm{Pu}-239)$ & $H=19 D=17$ & $A R=14 R R=18$ & $H=50-53, D=54-55$ & 250,330 \\
\hline \hline
\end{tabular}

${ }^{*} A R$-axial reflector. $\quad{ }^{\dagger} R R$-radial reflector.

Table 11 Masses and volumes of remaing reactor subsystem candidates and minimal power levels

\begin{tabular}{lccc}
\hline $\begin{array}{l}\text { Fuel with } \\
\text { Mo/Mo-Re } \\
\text { Cemet }\end{array}$ & $\begin{array}{c}\text { Expected reactor } \\
\text { subsystem } \\
\text { mass, } \mathrm{kg}\end{array}$ & $\begin{array}{c}\text { Expected reactor } \\
\text { subsystem } \\
\text { volume, } \mathrm{cm}^{3}\end{array}$ & $\begin{array}{c}\text { Expected reactor } \\
\text { subsystem power } \\
\text { rating, MWe }\end{array}$ \\
\hline $\mathrm{UN}$ & 870 & 220,000 & $\leq 10$ \\
$\mathrm{PuO}_{2}$ & 590 & 140,000 & $\leq 10$ \\
$\mathrm{PuN}$ & 510 & 65,000 & $\leq 10$ \\
\hline
\end{tabular}

(most of the time) volume reduction. We conservatively assume this modification is relevant to reactors intended for lower power ratings (few MWe as compared to $100 \mathrm{MWe}$ ) based on a desire to meet any power density limitations, or total life cycle fissile fuel burnup. Otherwise, we do not anticipate any disadvantages, or design difficulties from this reflector modifications.

\section{F. Some Resultant Preliminary Reactors Incorporating the Design Modifications}

Table 9 lists a few preliminary reactor configurations representing the mass and volume reductions due to nitride substitutions and/or reflector modifications in uranium-based Mo-Re cermets; Table 10 lists a few preliminary reactor configurations representing the mass and volume reductions due to nitride substitutions and/or reflector modifications in plutonium-based Mo-Re cermets. Table 11 lists masses and volumes of remaining candidates and minimal power level.

\section{Summary}

Of the preliminary reactor designs arrived at in Tables 9 and 10 , it is clear that an increased radial reflector thickness for lower power (under 10-MWe) reactors is an advantage in mass and volume savings at no cost in design and safety capabilities. Detailed evaluations of the impact 13 on the reactor lifecycle length, and the flooded and buried transient safety analyses may just require small additional $\mathrm{Re}$ to be incorporated in the vessel wall itself or lining. No other safety or performance properties are expected.

There is actually little experience in refractory cermet reactors for any of the ceramic fuels that are considerd. Uranium dioxide is the best known fuel, and plutonium dioxide (in MOX fuels) is known rather well. Also there is experience with $\mathrm{Pu}$ as a fuel in a few test (plate reactors) studies. UN has been tested and developed as a refractory fuel for the SP-100. PuN is not well known. There may still be strong incentives to not use plutonium that are unrelated to the intended reactor design. On the other hand, advantages may appear as a result of material tests in the plutonium oxide and nitride over the advantages in larger reflector thicknesses and UN use alone. Plutonium ceramics may finally be preferred when the peak temperature allowed for the various ceramics are determined. Material analyses to evaluate the stability of these fuels vs the temperature and time variables are still needed. Also, experimental evaluation of the migration rates of fissile materials through the refractory metal matrix and the coolant ducts at operating conditions should be determined because these can limit the maximum power levels and the reactor total designed energy delivery. Based on results from these auxiliary materials' irradiation and materials studies, the determination of the candidate fuels can finally be made. Thus, as far as cermet fuels are concerned, serious and interesting research should be conducted to select the best of the three candidates, or even candidates bearing americium fuels.

Finally, there are considerations that contribute to the mass of the reactor subsystem in Tables 8-11 that cannot be determined more accurately without further analyses such as the power level, thermal efficiency, shielding requirements, and material testing. For example, the vessel mass will depend on the pressure needed in the power cycle. This also will depend on the service environment, such as whether the subsystem is exposed to meteors or missiles. Also, the reactor subsytem mass is not the only factor in the total system mass because the power rate and efficiencies employed dictate the total gas (tanks and piping), as well as compressors and radiators needed.

\section{Acknowledgment}

This work was supported in part by the NASA Institute for Advanced Concepts of the University Space Research Association.

\section{References}

${ }^{1}$ Kammash, T., Proceedings of the First International Symposium on Beamed Energy Propulsion, AIP Conference Proceedings 664, AIP, New York, 2002, pp. 433-441.

${ }^{2}$ Snavely, R. A., Key, M. H., Hatchett, S. P., Cowan, T. E., Roth, M., Phillips, T. W., Stoyer, M. A., Henry, E. A., Sangster, T. C., Singh, M. S., Wilks, S. C., Mackinnon, A., Offenberger, A., Pennington, D. M., Yasuike, K., Langdon, A. B., Lasinski, B. F., Johnson, J., Perry, D. M., and Campbell, E. M., "Intense High-Energy Proton Beams from Peta-Watt-Laser Irradiation of Solids," Physical Review Letters, Vol. 85, No. 14, AIP, New York, 2002, pp. $2945-2948$.

${ }^{3}$ Tompkins, R. J., Mercer, I. P., Fettweis, M., Barnett, C. J., Klug, D. R., and Porter, L. G., "5-20 keV Laser Induced X-ray Generation at $1 \mathrm{KHz}$ from Liquid-Jet Target," Physical Review Letters, Vol. 69, No. 9, AIP, New York, 1998, pp. 3113-3117.

${ }^{4}$ Jahshan, S. N., and Borkowski, J. A., "A Gas Cooled Cermet Reactor System For Planetary Base Power," Nuclear Technology and Space Power, American Nuclearsociety, 1992, pp. 213-224.

${ }^{5}$ Jahshan, S. N., and Borkowski, J. A., "A Modular Gas Cooled Cermet Reactor System For Planetary Base Power," Proceedings of the Symposium on Space Nuclear Power, AIP, New York, Jan. 1993, pp. 641-647.

6"Nuclear Rocket ProgramTerminal Report," Argonne National Lab., Rept. ANL-7236, Argonne, IL, June 1966.

7 "Study of Gas-Cooled Fast Reactor Technoliogy," General Electric Co., Rept. GE-NMP-67-505, NASA CR-72321, 1967

8 "710 High Temperature Gas Reactor Program Summary Report," General Electric Nuclar Materials and Propulsion Operation, Rept. GEMP-6000, Vols. 1-5, 1969.

9"Design of Fast Test Facility for the 710 Fuel Elements based on a Neutron Filter," General Electric Co., Rept. GEMP-593, May 1968. 
${ }^{10}$ Jahshan, S. N., "The Reactor Physics Design of Gas Cooled Cermet Reactors and Their Potential Application to Space Power Systems," Nuclear Technology, Vol. 98, American Nuclearsociety, La Grange, IL, June 1992, pp. 237-276.

${ }^{11}$ Jahshan, S. N., Moore, R. L., and Lundberg, L. B., "Conceptual Design of a Refractory Materials Propulsion Reactor," Proceedings of the Symposium on Space Nuclear Power, AIP, New York, Jan. 1994, pp. 765-771.

${ }^{12}$ Tagawa, H., "Phase Relations and Thermodynamic Properties of the Uranium-Nitrogen System," Journal of Nuclear Materials, Vol. 51,
1974, pp. 78-86.

${ }^{13}$ Schultz, W. W., The Chemistry of Americium, ERDA Review Series, TID-26971, Energy Research and Development Administration, GPO, Washington, DC, 1976.

${ }^{14}$ Ronen, Y., and Leibstein, M. J., "Potential Applications of Am as a Nuclear Fuel," Nuclear Science and Engineering, Vol. 99, American Nuclearsociety, La Grange, IL, 1988, pp. 278-284.

${ }^{15}$ Kammash, T., Galbriath, D. L., and Jan, T. R., "An Americium-Fueled Gas Core Nuclear Rocket," Proceedings of the Symposium 030103, Vol. 271, AIP, New York, No. 1, 1993, pp. 585-589. 